\title{
mELIITTS
}

34.2.2018 [168-192]

\section{PROBLEM DUNIA ILMIAH DAN KRISIS SPIRITUAL}

\author{
Hubertus Hia $\quad$ Graduate Student \\ Faculty of Philosophy \\ Parahyangan Catholic University \\ Bandung, Indonesia
}

\begin{abstract}
:
Spiritual awareness is one's experience the living mind and body as a whole. It goes beyond mind and body, but also expands between the self and the world. At the center of human consciousness through the spiritual moments there is a sense of being deeply related with everything, the sense of being together with the whole universe. This kind of spiritual awareness has been threatened by the modern scientific world. The spirit of modernism to question and to break down nature, religion, and tradition under the pretext of pragmatic utopia of growth has brought humanity into an alarming and frightening phase of world civilization. Fritjof Capra says that the main problem of the existential crisis of modern humans is caused by the crisis of perception, mainly with the influence and errors from science as well as from Cartesian and Newtonian thoughts in perceiving the reality mechanically. Mysticism can be seen as an alternative to liberate modern humans to become authentic persons.
\end{abstract}

Keywords:

spiritual crisis • scientific world $\bullet$ mystery $\bullet$ cosmos $\bullet$ science $\bullet$ religion $\bullet$ mysticism

\section{Introduksi}

Dalam sejarah pembabakan ilmu pengetahuan, terdapat fase ketika manusia menjawab berbagai persoalan kehidupan secara mitologis. Dalam fase tersebut, dewa-dewi atau Tuhan berperan sebagai titik pusat arah jawaban yang valid, misalnya, dalam fenomena gempa, petir, gunung 
berapi, gerhana bulan, tsunami, atau ketika manusia ditimpa penyakit kusta. ${ }^{1}$ Kisah mitologis dapat ditemukan di setiap suku dan agama tradisional di seluruh dunia, termasuk di dalam agama-agama monoteistis. Dengan demikian, agama dan aliran kepercayaan memiliki peranan penting dalam perkembangan ilmu pengetahuan manusia, terutama sampai Abad Pertengahan.

Akan tetapi, manusia merupakan makhluk yang memiliki ketakjuban, ketidakpuasan, keraguan, dan hasrat untuk bertanya. ${ }^{2}$ Manusia adalah makhluk rasional (bomo rationale) yang haus akan pengetahuan. Oleh sebab itu, manusia selalu hidup dalam pencarian karena cenderung merasa tidak puas dan ragu tentang segala sesuatu. Ia berusaha mengungkapkan dan menaklukkan hasratnya untuk mencapai tujuan ultim, yakni kebahagiaan dan keselamatan; maka lahirlah Abad Pencerahan, yaitu era ketika matematika, fisika, kimia, astronomi, biologi, dan teknologi diterima sebagai jalan pencarian kebenaran. Kebenaran mitologis dan kebenaran agama mengalami keruntuhan, karena dipandang irasional dan tidak mampu mengeluarkan manusia dari kemelut kehidupan, sehingga manusia beralih pada dunia ilmiah-empiris.

Dalam Esai Filsafat untuk Masa Kini (1991), Louis Leahy mengatakan bahwa perkembangan ilmu dan sains tidak dapat dimengerti bila orang memisahkannya dalam kerangka pemahaman atas aliran kepercayaan dan agama monoteis, sebab aliran kepercayaan dan agama monoteis merupakan titik pijak sains dan teknologi. Lebih lanjut, Leahy mengatakan bahwa radikalisme agama monoteis telah mendorong perubahan pola kesadaran manusia dalam mempersepsi alam semesta seturut kerangka aturan dan hukum, yakni ketika sains berusaha membongkar kedangkalan berpikir agama yang terlalu arogan karena membuat manusia frustrasi dalam memaknai kehidupan di dunia. ${ }^{3}$ Di masa kini, orang sudah merasakan hasil kesuksesan ilmu dan sains dalam membongkar klaim kebenaran dari mitos, tradisi, doktrin agama, dan bahkan alam semesta. Ketika tidak mampu memberikan jawaban yang bersifat empiris, logis, dan aktual, agama cenderung ditinggalkan dan bahkan ditolak, apalagi ketika agama kehilangan orientasi di zaman kini sebagai pembawa keselamatan dan penafsir kehidupan.

Dalam The Consequences of Modernity, Anthony Giddens mengatakan bahwa manusia modern telah kehilangan makna hidup lantaran begitu 
arogan meruntuhkan nilai-nilai yang ada di dalamnya, salah satunya adalah dengan mengeksploitasi alam demi eksperimen, sementara harapannya ialah tindakan tersebut menjadi jembatan ruang dan waktu secara kontinyu antara masa lalu, masa kini, dan masa depan. ${ }^{4}$ Bentuk refleksi modernitas dan saintifik berupa informasi "yang tampak" lebih menawarkan kepastian, kebenaran objektif, dunia yang penuh irama kemajuan dan kecanggihan, tetapi cenderung tanpa rima. ${ }^{5}$ Dengan kata lain, modernitas menggiring manusia pada kemajuan di suatu daerah padang gurun. Pada Abad ke-20, beberapa fisikawan seperti Fritjof Schuon, Ken Wilber, dan Fritjof Capra mengamati bahwa metode ilmiah, terutama dari Descartes dan Newton bersifat serba mekanistis-linier, analitik, deskriptif, dan objektif, serta tidak seluruhnya mampu mengungkapkan misteri dunia ini. Ilmu dan sains memiliki keterbatasan, yakni hanya memperhatikan unsur eksterior yang tampak. Sementara itu, dunia bukanlah melulu benda mati, melainkan adalah realitas yang dinamis, punya tujuan, bernilai, dan otonom pada dirinya sendiri. Melalui teori evolusi genetika dan memetika, orang menemukan bahwa kosmologi senantiasa berubah. Walaupun dalam Teori Evolusi ditemukan persoalan-persoalan menarik, seperti apakah orang menerima evolusi tanpa Tuhan, Tuhan tanpa evolusi, atau evolusi bersama Tuhan, Capra mengatakan bahwa Tuhan adalah dinamika swa-organisasi atau energi dari keseluruhan kosmos. ${ }^{6}$ Fritjof Capra adalah penganut aliran pan-enteistik yang mengakui bahwa segala bentuk material merupakan manifestasi roh. ${ }^{7}$ Di sini, identitas Tuhan bukan lagi sebagai Tuhan yang berwajah personal sebagaimana dipercayai oleh agama monoteis, melainkan yang bersifat energi dan ada di dalam alam semesta, serta juga hadir di dalam diri dan kesadaran manusia.

Tulisan ini berada di wilayah postmodernisme. Postmodernisme adalah suatu gerakan sikap kritis terhadap mentalitas dan gejala-gejala kebudayaan manusia modern atau upaya menanggapi berbagai masalah modernisme, seperti kapitalisme, teknokulturalisme, positivisme, dan saintisisme yang menekankan kebenaran empiris dan rasional. Selain itu, postmodernisme merupakan masa kebangkitan kesadaran manusia yang meliputi pentingnya menghidupkan kembali dimensi spiritual. ${ }^{8}$ 


\section{Perkembangan Orientasi Pengamatan Dunia Ilmiah}

Ilmu sains tidak pertama-tama menelaah hal-hal yang paling dekat dengan manusia, seperti ilmu biologi yang menganalisis unsur fisiologis manusia maupun hewan, atau ilmu botani yang menganalisis tumbuhtumbuhan. Yang menjadi orientasi awal pengamatan sains yaitu bintang, matahari, bulan, dan anasir utama alam semesta, misalnya dari mana dunia ini berasal, mengapa dan apa yang membuat dunia tetap bertahan, apa tujuan dunia, kemudian dari sana melangkah ke perkara manusiawi yang dekat dengan diri manusia. ${ }^{9} \quad$ Melalui sejarah filsafat Yunani, orang menemukan para pemikir helenis seperti Thales, Anaximenes, Phytagoras, Heraklitus, Parmenides, Plato, Aristoteles, hingga filsuf dan teolog seperti Agustinus dari Hippo dan Thomas Aquinas. Mereka mengawali pengamatan atas objek yang bersifat transenden dan mencari anasir utama dari alam semesta. Oleh karenanya, tujuan hidup manusia pun terarah pada suatu esensi yang bersifat fundamental, baik disebut sebagai makna, tak ternamai, roh, energi, dewa-dewi, atau Tuhan. Pada dasarnya, ruang dan waktu pencarian tersebut tidak lepas dari eksistensi alam semesta.

Dalam pencarian prinsip fundamental, muncul konsekuensi terhadap perubahan paradigma manusia terhadap alam semesta, yakni dari konsep alam yang bersifat organis, kudus, rumah dewa-dewi, wajah ibu, dan beralih pada konsep alam yang mekanistik, benda mati, dan semata-mata objek penelitian. Pertanyaan lebih lanjut yakni apakah perubahan konsep tersebut dapat dipandang sebagai keberhasilan manusia membebaskan diri dari kebodohan para leluhur yang dianggap tidak berpendidikan ilmiah? Apakah semua merupakan bukti kecerdasan dan hasil keberhasilan manusia dalam mengungkapkan fakta alam semesta yang sesungguhnya? Apakah dunia ilmiah telah berhasil memberikan kesejahteraan yang lebih besar terhadap manusia untuk menggapai tujuan ultimnya? Lantas, apakah manusia modern lebih bahagia daripada manusia yang hidup sebelum abad ke-16, misalnya?

Hal yang lebih menarik direfleksikan ialah bahwa manusia zaman sekarang memiliki paradigma berbeda tentang hakikat alam dan Tuhan, yang sangat berbeda dibanding sebelum abad ke-16. Perubahan perspektif manusia modern terhadap alam dan Tuhan membawa perubahan pada konsep manusia terhadap agama, tradisi atau kebudayaan lokal. Pada 
umumnya, konsep teologis agama monoteis dan teristimewa agamaagama tradisional tidak terlepas dari konsep keberadaan alam yang bersifat organis, yang menonjolkan kehadiran sosok supranatural. Dengan kata lain, agama tradisional biasanya bertumbuh, berkembang, dan hidup berdampingan dengan alam. Agama tradisional juga lebih berkembang di tengah masyarakat pedesaan yang masih belum terkontaminasi teknologi dan teknokulturalisme. Dengan demikian, perubahan konsep manusia terhadap alam yang bersifat organis menjadi nonorganis membawa konsekuensi pudarnya budaya-budaya lokal dan bahkan melemahnya pengaruh agama-agama besar. Hal yang lebih fundamental barangkali adalah kematian spiritual, sedangkan esensi agama, budaya tradisional, dan Tuhan terutama adalah bersifat spiritual. ${ }^{10}$

\section{Eksistensi Manusia sebagai Makbluk yang Takjub dan Pengembara}

Apakah manusia merupakan satu-satunya makhluk yang memiliki rasa takjub? Aristoteles mengatakan bahwa kelahiran filsafat berawal dari pengalaman kekaguman dan ketakjuban manusia terhadap benda atau realitas di sekitarnya. Ketika merasa takjub pada siklus perubahan antara malam dan siang, manusia termotivasi untuk melakukan penelitian terhadap peredaran matahari, bulan, planet, tempat planet dan galaksi, dan bahkan berikhtiar mencari asal mula alam semesta. ${ }^{11}$ Perasaan takjub atau kekaguman manusia terhadap objek-objek tertentu mendorong akhirnya manusia melakukan penelitian terus menerus dengan berbagai metode dan alat yang juga semakin canggih. ${ }^{12}$

Dalam perkembangan refleksinya, manusia tidak hanya kagum, heran atau takjub terhadap fenomena alam yang berada di luar dirinya, tetapi juga terhadap hukum moral di dalam hatinya (Immanuel Kant). Manusia juga mampu memahami kesadarannya sendiri atau menganalisis pikirannya sendiri yang sedang berpikir (Rene Descartes). Identitas manusia sebagai makhluk yang takjub dan pengembara telah membuat wajah dunia ini, yakni alam, kultur-sosial, dan pemahaman manusia tentang eksistensinya terusmenerus berubah dan berevolusi. Capra mengatakan bahwa pengertian evolusi yang tepat di zaman sekarang bukanlah pemahaman evolusi dalam tataran biologis seperti evolusi genetik manusia dari homo erectus, pra homo sapiens, Neanderthal, Cro-Magnon, sampai manusia modern. ${ }^{13}$ Ia menyatakan 
bahwa evolusi biologis atau genetik sudah berhenti kira-kira lima ribu tahun yang lalu. Sebaliknya, pengertian evolusi di zaman sekarang, ialah evolusi dalam konteks sosial dan kultur. ${ }^{14}$

Evolusi kultur merupakan simbol identitas manusia sebagai makhluk pengembara, yang takjub, rasional, dan merupakan pengaruh dari identitas manusia sebagai makhluk spiritual. Evolusi kultur terjadi karena sikap manusia yang terus menerus menyempurnakan diri, baik secara kolektif maupun individual. Selain itu, evolusi kultur merupakan hasil refleksi dan aksi manusia terhadap situasi letak geografis dan mentalitas lingkungan tempat mereka tinggal. Ketika manusia mengalami evolusi kebudayaan, pasti ada perubahan. Muncul pertanyaan reflektif: apakah perubahan tersebut mengarah pada krisis atau bersifat membangun? Menurut Capra, perubahan kultur berada dalam dua persimpangan, yaitu di antara krisis atau kesempatan. ${ }^{15}$ Pada zaman sekarang, orang telah memasuki pembabakan kultur baru, yakni peradaban modernitas, ketika teknologi dan sains mewarnai seluruh pekerjaan dan kesadaran manusia. Peradaban modernitas dapat dilihat sebagai kultur yang berada di tengah persimpangan, sebagai bukti keberhasilan dan kemajuan manusia, namun sekaligus dapat dipandang sebagai zaman ketika manusia hidup dalam bayang-bayang ketakutan, kegelisahan, kesepian, dan kekeringan jiwa. ${ }^{16}$

\section{Manusia Membebaskan Diri dari Kemelut Mitos dan Agama}

Di setiap suku, dapat ditemukan berbagai unsur mitologis, misalnya, dalam bentuk amsal, teka-teki, atau dongeng, yang berupaya menjelaskan asal mula alam semesta (mite kosmogonis) dan berbagai sifat peristiwa dari alam semesta (mite kosmologis). ${ }^{17}$ Melalui mitos, manusia berikhtiar menjelaskan sesuatu yang substansial, seperti asal dan tujuan kehidupan manusia dan alam. Dalam mitos, kehadiran dewa-dewi atau Tuhan (dalam konteks agama monoteis) merupakan suatu sosok eksistensial yang niscaya selalu ada, dan berperan penting sebagai arah seluruh jawaban.

Sejarah filsafat Yunani menekankan peran mitos dalam kehidupan manusia. Mitos pada level ini menjadi tahap awal perkembangan filsafat, agama monoteis, dan juga dunia ilmiah modern. Artinya, mitos dalam sejarah pembabakan metodologi ilmu pengetahuan pernah digunakan untuk menjelaskan makna kehidupan, seperti juga ditemukan dalam peran 
wayang di suku Jawa ataupun syair-syair Homeros yang berjudul Illias dan Odyssea dalam kesusastraan Yunani. ${ }^{18}$ Akan tetapi, di tengah legitimasi ilmiah kini, mitos sering dipandang sebagai (ilmu) pengetahuan yang keliru, irasional, dan tidak dapat dipertanggungjawabkan secara empiris. Walaupun demikian, lewat mitos dapat ditemukan dua hal penting. Pertama, manusia memiliki kemampuan mengabstraksi sesuatu yang belum pernah dialaminya. Melalui mitos diungkapkan daya brilian yang dimiliki manusia, yakni intuisi dan imajinasi, yang tampaknya justru semakin terkekang di zaman modern. Kedua, mitos memperlihatkan nilai filosofis makna kehidupan, meskipun di balik mitos itu pada dasarnya manusia pun dibuat semakin ragu terhadap peristiwa-peristiwa yang pernah terjadi. Manusia pada dasarnya adalah makhluk yang memiliki keraguan atau rasa sangsi. ${ }^{19}$ Manusia cenderung merasa tidak puas, senantiasa mencari penjelasan dan keterangan tentang hakikat kebenaran lewat kelogisan, sistematisasi, dan kesesuaian akurat antara gagasan dan fakta. Ketika mitos tidak dapat diverifikasi kebenarannya secara empiris, dengan sendirinya akan cenderung dipertanyakan, diragukan, dan ditinggalkan karena dipandang bersifat irasional.

Dengan demikian, perjalanan tumbangnya peradaban mitologis di hadapan legitimasi sains menjadi simbol eksistensi manusia yang semakin bersifat rasional. Oleh karenanya, agama pun tidak dapat menghindar dan pada suatu ketika ikut terseret dalam keraguan sains. Pada umumnya, paradigma berpikir agama cenderung bersifat mitologis dan sumber dogma agama monoteistik banyak berkembang dari mitos yang dirasionalisasi secara filosofis dan teologis. ${ }^{20}$ Alasan lain yang menyebabkan agama terseret ke dalam keraguan, ialah karena didorong oleh sikap arogan agama sendiri ketika mengklaim kebenaran absolut. Ketika agama cenderung membuat manusia merasa frustasi dan gelisah karena penggunaan kekerasan, atau di saat agama tidak dapat memberi ruang bagi manusia untuk mengekspresikan kebebasan memaknai hidup, manusia pun mencari jalan lain di luar agama. Dalam hal ini, agama memicu manusia mengembara dan melakukan eksperimen. Tampaknya tidak salah apabila dikatakan bahwa agama pun merupakan salah satu akar pertumbuhan modernisme atau dunia ilmiah, dan sekaligus juga penyebab krisis spiritual. 


\section{Manusia Membebaskan Diri dari Kemelut Alam}

Berangkat dari refleksi filosofis, evolusi peradaban merupakan konsekuensi aktualiasi eksistensi manusia sebagai mahkluk bebas. Menurut Jean-Paul Sartre, kebebasan adalah identitas, eksistensi dan ontologi manusia itu sendiri. Inti kebebasan manusia yaitu kemampuan berpikir secara rasional dan berdistansi terhadap kesadarannya sendiri. ${ }^{21}$ Kebebasan dapat dipandang sebagai suatu nilai ultim tujuan hidup manusia atau roh yang mendorong manusia untuk bergerak dan bertindak.

Akan tetapi, kebebasan manusia sering terbentur pada berbagai situasi batas, terutama situasi alam yang tidak bersahabat dengan manusia untuk mengekspresikan dirinya mencapai tujuan ultim. Situasi tersebut membuat manusia berada dalam kesengsaraan dan penderitaan, bahkan membuat manusia tidak berdaya, baik secara fisik maupun psikis. Bentuk-bentuk situasi alam yang tidak bersahabat dengan manusia terlihat pada fenomena alam seperti bencana alam serta berbagai jenis penyakit baru. ${ }^{22}$ Akibatnya, kebebasan manusia seakan-akan diobrak-abrik oleh alam dan akhirnya manusia malah memandang alam sebagai musuh yang harus ditaklukkan. Suatu ketika alam dipandang sebagai sesuatu yang asing, karena lain dari diri manusia. ${ }^{23}$ Manusia meninggalkan konsep tentang alam sebagai milik dewa-dewi atau Tuhan, dan tidak lagi menerima peran Tuhan sebagai penggerak utama berbagai peristiwa semesta. Pada saat itu, manusia semakin tergerak untuk mengembangkan teknologi dan penelitian ilmiah. Dengan kata lain, manusia tidak lagi tunduk pada kuasa alam dan tidak menggantungkan harapannya pada dewa-dewi atau Tuhan. Ketika berada dalam penderitaan, manusia merasa dirinya tidak bebas. Oleh sebab itu, manusia sebagai makhluk yang rasional terdorong untuk mencari jawaban yang lebih tepat untuk memenuhi kebutuhannya.

Pada dasarnya penderitaan bertentangan dengan konsep kebahagiaan sebagai tujuan akhir hidup manusia. Oleh sebab itu, manusia berusaha meminimalisasi penderitaan dan kesengsaraan dengan berbagai cara. Menurut Jeremy Bentham, alam telah menempatkan manusia di bawah dua kekuasaan yang berdaulat, yakni rasa sakit dan kesenangan. Di satu sisi, alam dapat memberikan kesenangan kepada manusia, tetapi di sisi lain alam juga banyak membuat manusia menderita. Dalam pandangan Bentham, sifat dasar manusia adalah berusaha mengejar kesenangan dan 
menghindari penderitaan atau rasa sakit, hingga akhirnya dapat mencapai kesenangan yang paling besar dan dalam jumlah yang besar. Pandangan utilitarianisme dan hedonisme ini terkait dengan keinginan manusia membebaskan dirinya dari penderitaan. ${ }^{24}$

\section{Para Pemikir yang Mempengaruhi Paradigma Ilmiah}

Dalam bagian ini, saya menggunakan pengamatan Capra tentang para pemikir yang mempunyai pengaruh besar pada kelahiran peradaban modern di zaman sekarang. Capra mengatakan, misalnya, bahwa Isaac Newton, Francis Bacon, Rene Descartes, Thomas Hobbes merupakan pemikir yang memiliki pengaruh sangat kuat terhadap peradaban ilmiah dan teristimewa di Barat pada umumnya, dan bahwa pengaruh mereka masih dirasakan sampai kini. ${ }^{25}$

\section{Nicolaus Copernicus, Yohanes Kepler, dan Galileo Galilei}

Perkembangan ilmiah terjadi ketika Nicolaus Copernicus (1473-1543) berhasil membuktikan kekeliruan keyakinan Gereja tentang kedudukan bumi sebagai pusat tatanan kosmos (geosentris). Menurut Copernicus, bumi merupakan salah satu dari ribuan planet yang juga turut berputar mengelilingi matahari sebagai titik pusat seluruh planet (heliosentris). ${ }^{26}$ Meskipun begitu, Copernicus memilih menunda menerbitkan buku tersebut dan mengatakan bahwa ide itu hanya hipotesis. Ia mengetahui bahwa idenya dapat memicu permasalahan besar dan bahkan mengancam hidupnya, karena mendobrak tradisi Gereja sebagai lembaga yang memiliki otoritas tertinggi.

Perkembangan ilmiah berlanjut melalui Yohanes Kepler (1571-1630), yang meneruskan dan mengoreksi teori-teori sebelumnya, termasuk teori Copernicus tentang pergerakan planet dalam bentuk lingkaran, yakni bahwa bumi berputar setiap hari pada sumbunya dan sekaligus mengelilingi matahari. Kepler mengatakan bahwa planet-planet bergerak dalam lintasan berbentuk elips, dan gerakan tersebut bersifat dinamis, yakni lebih cepat di bagian orbit tertentu dan melambat di bagian lainnya. ${ }^{27}$ Melalui Kepler, perkembangan ilmiah semakin terbuka terhadap eksperimen langsung dan bukan karena asumsi abstrak sebagaimana dilakukan oleh Copernicus.

Galileo Galilei (1564-1642) dapat disebut sebagai pelopor sains yang pertama kali terlibat konflik dengan Gereja karena keberaniannya 
menyatakan secara publik bahwa bumi berputar pada sumbunya dan mengelilingi matahari. ${ }^{28}$ Pada 1633, Galileo dijatuhi hukuman publik dari otoritas Gereja, tetapi penemuan Galilei membuka pintu bagi perkembangan sains yang sama sekali baru. Pertama, teori gravitasi sebuah benda, yaitu bahwa setiap benda akan jatuh dengan kecepatan yang sama, tidak peduli berapa beratnya, asalkan tidak ada pengaruh dari luar. ${ }^{29} \mathrm{Kedua}$, pengalaman-pengalaman fisik yang paling langsung dan paling dekat, seperti warna dan bau, harus secara sistematis disingkirkan dari catatan pengalaman ilmuwan karena bersifat subjektif. ${ }^{30}$ Artinya, kesimpulan yang berasal dari asumsi dan tanpa diverifikasi tidak dapat diterima sebagai kebenaran. Galileo memberikan suatu pernyataan metaforis, yakni bagaimana mungkin otoritas Gereja yang bukan dokter berani meracik obat? Hal itu akan mengancam nyawa pasien. ${ }^{31}$ Dalam hal ini, Galileo mendesak agar Gereja tidak mencampuri aktivitas para ilmuwan, dan hendak mengungkapkan pernyataan tentang kebenaran baru di hadapan agama dan umat manusia, yakni yang disebut kebenaran ilmiah. ${ }^{32}$

Ketiga pemikir tersebut meletakkan dasar bagi perkembangan sains dan berperan melepaskan belenggu para ilmuwan dari genggaman otoritas agama. Konsekuensilebih lanjutialah bahwa mereka memunculkan polemik baru, yakni mendorong manusia pada keraguan yang mempertanyakan kebenaran ajaran agama, termasuk kebenaran Kitab Suci dan juga eksistensi Tuhan. Selain itu, para pemikir itu juga menurunkan manusia dari kesombongan dirinya sebagai makhluk yang berkuasa atas alam. ${ }^{33}$

\section{Francis Bacon}

Francis Bacon $(1561-1626)^{34}$ tergolong pelopor yang berjasa mensistematisasi prosedur ilmiah secara logis. Sepanjang hidupnya, Bacon berusaha membawa filsafat, ilmu pengetahuan yang lama, dan bahkan teologi ke dalam wilayah praktis, yakni agar semua ilmu pengetahuan memiliki implikasi pragmatis. Baginya, tujuan ilmu pengetahuan ialah mewujudkan kesejahteraan dan kemakmuran manusia, dan sains hadir untuk mewujudkan harapan itu. Dalam pandangan Bacon, alam seakanakan harus "diburu dalam pengembaraannya", "diikat dalam pelayanan", "dijadikan budak", "dimasukkan ke dalam kerangkeng", dan bahwa tujuan para ilmuwan ialah "mengambil rahasia alam secara paksa". 35 Menurut Capra, Bacon adalah orang yang memiliki pengaruh kuat dan memunculkan sikap patriakhal dalam pemikiran di dunia ilmiah. ${ }^{36}$ 
Selain itu, Bacon mengatakan bahwa tugas ilmu pengetahuan ialah membasmi keyakinan yang tidak berasal dari kebenaran berdasarkan eksperimen, ajaran sesat, serta pandangan yang keliru. ${ }^{37}$ Pengetahuan yang sahih adalah pengetahuan yang diperoleh dari hasil pengamatan atas fakta secara akurat. Dengan demikian, seseorang yang ingin mencari kebenaran harus 'mewawancarai' alam, bekerja menurut suatu metode yang benar, dan menghindari sikap berprasangka. ${ }^{38}$ Dalam pandangan Bacon, metode yang penting dalam perkembangan dunia ilmiah ialah metode empiris dan induktif. Metode tersebut telah merambah berbagai bidang di peradaban modernitas sampai sekarang.

\section{Thomas Hobbes}

Dalam pandangan Thomas Hobbes (1588-1679), alam semesta merupakan sebuah mesin raksasa. Karakter sebuah mesin adalah bersifat mekanistik. Artinya, mesin memiliki dimensi ukuran panjang, lebar, kedalaman, dan juga bergerak dengan hukum yang serba teratur dan tetap, ibarat kerja tubuh manusia. ${ }^{39}$ Hanya saja, tubuh manusia bersifat mikro, sedangkan alam semesta bersifat makro. Maka, Hobbes dapat disebut sebagai seorang penganut naturalisme, materialisme, mekanisme, behaviorisme, dan teori gerak sebab-akibat atau kausalitas. ${ }^{40}$ Pemikiran Hobbes hampir mendominasi ilmu psikologi dan juga filsafat politik, yakni ketika masyarakat dianalisis secara psikologis-mekanistik. Menurut Hobbes, alam semesta adalah segala-galanya, maka segala sesuatu yang tidak menjadi bagian dari alam semesta adalah tidak ada. ${ }^{41}$ Di samping itu, Hobbes juga berupaya untuk menyerang eksistensi Tuhan, sebab baginya eksistensi Tuhan merupakan sesuatu yang kontradiktif dan tidak bermakna.

\section{René Descartes}

René Descartes hidup pada 1956-1650 dan lahir di La Haye, Perancis. Awal pemikiran Descartes berawal dari mimpi, ketika ia mengalami penglihatan yang dianggapnya sebagai wahyu Tuhan. ${ }^{42}$ Dalam pewahyuan itu, ia didorong untuk membangun sebuah metode dan ilmu alam yang lengkap dan pasti, yakni suatu ilmu yang didasarkan pada prinsip dan dapat dibuktikan sendiri, seperti halnya matematika. ${ }^{43}$ Visi Descartes adalah menumbuhkan keyakinan kuat pada diri dan seluruh manusia 
tentang kepastian pengetahuan ilmiah, dan tugas dalam kehidupan ialah membedakan semua kebenaran dari semua kesalahan bidang pelajaran. ${ }^{44}$ Menurut tanggapan filsuf Bertrand Russel, Descartes telah melahirkan peradaban baru, yakni suatu tanda ketika manusia mengalami kepercayaan diri dengan pengetahuannya. ${ }^{45} \mathrm{Hal} \mathrm{ini} \mathrm{belum} \mathrm{terjadi} \mathrm{pada} \mathrm{zaman} \mathrm{Aristoteles.}$ Manusia mulai dari dirinya sendiri sebagai subjek pemikiran dan titik tolak kebenaran itu sendiri. ${ }^{46}$ Bukan hanya dipandang sebagai pengaruh kolonialisme Barat, tetapi kesadaran kolektif manusia sudah cenderung menerima kepastian sebagai tolak ukur kebenaran yang valid, yaitu di dunia ilmiah. Menurut Capra, banyak orang di masyarakat, baik ilmuwan maupun awam, meyakini bahwa metode ilmiah merupakan satu-satunya cara yang baik untuk memahami alam semesta. ${ }^{47}$

Dari Descartes, kunci alam semesta terletak dalam struktur matematika, dan dalam pikirannya ilmu itu sinonim dengan matematika. ${ }^{48}$ Dengan kata lain, Descartes menganggap bahwa bahasa alam adalah matematika. Alam semesta tidak lain adalah suatu materi dan sekadar mesin, maka alam tidak punya tujuan, kehidupan, dan spiritualitas di dalamnya. ${ }^{49}$ Alam bekerja sesuai dengan hukum-hukum mekanistik, dan segala sesuatu dalam dunia materi dapat diterangkan dalam pengertian tatanan dan gerakan dari bagian-bagian. ${ }^{50}$ Gambaran Descartes tentang hakikat alam yang matematis membawanya pada penemuan baru yang masih dikenal sampai sekarang, yakni matematika geometri analitik, yang memungkinkan untuk mempelajari bintang-bintang yang bergerak, sesuai dengan skema besarnya untuk mereduksi semua fenomena fisik menjadi hubungan matematis yang pasti. Descartes mengakui bahwa seluruh fisikanya tidak lain adalah geometri. ${ }^{51}$ Sebab itu, Descartes mengakui eksistensi Tuhan sebagai penggerak utama atau pencipta alam semesta. Alam semesta bagaikan sebuah arloji yang bergerak dan hidup sendiri, tetapi mesin arloji tersebut ada dan bergerak karena ada penciptanya. Dalam hal ini, tampaknya ada kontradiksi dengan pemikiran Descartes bahwa alam semesta tidak punya tujuan, sebab bila diibaratkan dengan arloji, yakni bahwa seseorang yang berikhtiar menciptakan arloji pasti memiliki tujuan, baik sebatas tujuan berekreasi maupun sampai pada maksud yang lebih tinggi. Artinya, alam semesta tetap memiliki tujuan, dan tujuan selalu berkaitan dengan makna, dan makna merupakan wilayah 'spiritual'. ${ }^{52}$ Akan tetapi, eksistensi Tuhan semakin hilang dan dilupakan dalam aliran Cartesian hingga sekarang, 
karena para penganutnya terlalu memberikan perhatian pada keadaan alam sebagai yang mekanistik.

Apa sebenarnya sumbangan Descartes pada perkembangan dunia ilmiah? Pertama, penemuannya bahwa hakikat bahasa alam adalah matematis (geometri). Kedua, metode ilmu yang sahih adalah deduksi, sebab matematika merupakan ilmu yang menyentuh prinsip fundamental, sehingga metode deduksi matematika mustahil salah bila dilakukan dengan perhitungan yang benar. Ketiga, dalam filsafat Descartes, penggunaan daya intuisi telah dikembangkan, namun model intuisi dalam filsafat Descartes telah terkontaminasi oleh pengakuan kebenaran dari sikap deduksionis matematis. Kekuatan intuisi yang seharusnya mampu melihat hakikat alam secara holistik dan organis menjadi terpecah-pecah, dan alam lebih merupakan benda mati dan bersifat statis, atau bahwa fenomena alam terkurung dalam sebuah perhitungan prinsip mekanistik tunggal. ${ }^{53}$ Keempat, metode analitik Descartes bermanfaat bagi perkembangan teori ilmiah, seperti perkembangan pelaksanaan berbagai proyek teknologi yang kompleks dan memungkinkan untuk mengirim manusia ke bulan.

\section{Isaac Newton}

Isaac Newton (1942-1727) berhasil menguraikan dengan tepat unsurunsur pembentuk cahaya. Ia menemukan kalkulus diferensial untuk menjelaskan dan menggambarkan gerak benda padat, ${ }^{54}$ merumuskan konsep gerak tarik atau gravitasi bumi,${ }^{55}$ mengoreksi dan menyempurnakan teori Galilei dan Descartes yang jauh melampaui metode teknik matematika. Dalam pandangan Newton, alam semesta pada mulanya diciptakan oleh Tuhan dengan partikel benda, kekuatan antarpartikel, dan hukum gerak dasar. Mulai saat itu, alam semesta bergerak dan terus bergerak seperti sebuah mesin raksasa, yang diatur oleh hukum-hukumnya. ${ }^{56}$ Dalam pemikiran mekanistik Newton, alam semesta beserta fenomenanya merupakan gerak partikel benda, yang disebabkan oleh kekuatan daya tarik menarik atau kekuatan gravitasi. ${ }^{57}$ Ada cerita tentang pemikiran Newton dengan seorang awam yang pekerjaannya setiap hari adalah petani tanpa berpendidikan akademik. Inti pertanyaannya ialah tentang definisi meja. Ketika ditanyakan kepada seorang awam, apa itu meja, dijawab: meja adalah benda mati dan keras. Sementara itu, menurut Newton meja adalah daya yang terpadatkan, dan bukan balok kayu mati. Meja merupakan desakan- 
desakan aktivitas elektron-elektron yang beredar mengelilingi nukleinya sebanyak jutaan miliar kali dalam satu detik. ${ }^{58}$ Selain itu, penerapan teori mekanistik tidak hanya pada benda keras, tetapi juga direduksi pada fenomena benda cair, misalnya, bahwa panas adalah energi yang dihasilkan oleh suatu gerakan 'bergoncang' kompleks dari atom atau molekul. ${ }^{59}$

Newton menyimpulkan bahwa unsur dunia partikel materi; objek kecil, padat, dan tidak dapat dihancurkan. Filsafat alam Newton dipengaruhi oleh filsafat Phytagoras yang mengatakan bahwa anasir utama alam semesta adalah angka, sebab seluruh kenyataan atau realitas dapat dicocokkan dengan kategori matematis rasio manusia. ${ }^{60}$ Newton memberikan sumbangan besar terhadap perkembangan dunia ilmiah, misalnya, penelitian tentang fenomena listrik dan magnetik oleh Faraday dan Maxwell, dan selain itu, pengaruh Newton dan Descartes telah mempengaruhi perkembangan ilmu biomedis, psikologi, dan ekonomi. ${ }^{61}$

\section{Sumbangan Dunia Ilmiah pada Kesejahteraan Manusia}

Sains memiliki sumbangan besar dalam menggiring manusia untuk mencapai keselamatan dan kebahagiaan, baik secara material maupun intelektual. Ketika sains dalam tataran ini mengedepankan kejujuran, kemajuan, kebebasan, kesetaraan, dan menciptakan kultur yang beradab. Tujuan awal sains adalah membebaskan manusia dari kekeliruan agama mendefinisikan esensi realitas, dan menciptakan ruang dan waktu sehingga manusia tidak dibelenggu oleh kemelut fisik dan psikis, baik pengaruh alam maupun sosial-kultural. Ada tiga aspek esensial ikhtiar saintifik untuk menciptakan kebebasan, kemerdekaan, dan kebahagiaan manusia tersebut, yaitu menggunakan instruksi teknis, menangkap pengertian realitas secara langsung dengan domain atau data, serta menggunakan kebenaran konfirmasi kolektif atau pengujian. Menurut Y. B. Mangunwijaya, sains tidak salah, sebab kodratnya yaitu pengkotak-kotakkan diri dalam spesialisasi agar melihat sesuatu dengan jelas. ${ }^{62}$ Namun, sains perlu menyadari konsekuensi kodrat keterbatasannya, terutama sikap praktiknya yang cenderung bebas nilai (value free), sebab bila sebuah ilmu pengetahuan bersifat bebas nilai, ada kemungkinan menjadi dekstruktif. ${ }^{63}$

Tujuan sains, selain usaha emansipasi manusia dari berbagai tantangan yang mengancam eksistensi, juga mewujudkan kreativitas dan kecerdasan manusia. Keistimewaan eksistensi manusia dibandingkan makhluk 
lain tampak dari hasil konkret usaha manusia untuk melakukan atau menciptakan berbagai hal yang memukau, di luar batas kebiasaan yang alami. ${ }^{64}$ Di zaman sekarang, teknologi semakin berkembang. Teknologi dan sains tidak dapat dipisahkan, sebagaimana juga sains dan matematika. Teknologi merupakan hasil dari sains sekaligus menjadi instrumen untuk perkembangan sains itu sendiri. ${ }^{65}$

Identitas manusia sebagai makhluk bekerja (bomo faber) telah menciptakan berbagai teknologi canggih dan mampu memperpanjang kehidupan manusia, bahkan hasil kreasi manusia mampu menciptakan robot yang mirip dengan diri manusia sendiri. Artinya, keberhasilan sains tidak bisa diragukan lagi dalam membangun kesejahteraan hidup manusia secara langsung dan nyata. Sains berhasil mewujudkan secara konkret berbagai bentuk utopia kebahagiaan dan keselamatan yang dijanjikan oleh agama dan tradisi kebudayaan lokal. Sains dan teknologi dalam hal ini mewujudkan kebebasan manusia, meningkatkan standar kehidupan manusia, menciptakan kesempatan luas bagi manusia untuk memilih dan memberikan waktu senggang yang lebih banyak bagi manusia. ${ }^{66}$

\section{Sains dan Kelemahan Pendekatannya terhadap Realitas}

Ada keterbatasan dunia ilmiah (sains) dalam mempersepsi realitas, terutama kelemahan dan kekeliruan dari metode yang digunakan, yang acap kali bersifat destruktif daripada dekonstruktif. Dengan kata lain, sering kali ditwarkan pengetahuan yang sifatnya terpecah-pecah daripada pengetahuan yang utuh. Selain itu, ada konsekuensi kesalahan dunia ilmiah dalam menafsir kebenaran agama dan tradisi atau bagaimana modernisme melahirkan krisis spiritual. Penjelasan tentang kelemahan sains di sini tidak didasarkan perbandingan teoretis murni, seperti dalam fisika, matematika, atau kimia, melainkan secara filosofis dengan menggunakan pandangan filsuf Whitehead dan Capra, yang memiliki latar belakang pendidikan sains.

\section{Alfred North Whitehead ${ }^{67}$}

Menurut A. N. Whitehead (1861-1947), dalam peradaban modernisme (khususnya saintisisme) ada satu bidang ilmu pengetahuan yang memiliki peranan penting, yaitu matematika. Sains tidak dapat dipisahkan dengan matematika, sebab seluruh dasar sains adalah matematika, misalnya, geometri, aritmatika, trigonometri, atau aljabar. Ilmu pasti seperti 
matematika menurut Whitehead adalah sebentuk abstraksi murni pemikiran manusia tentang realitas, misalnya geometri adalah mengenai ukuran alam semesta. Dengan demikian, matematika adalah hasil persepsi, kesadaran, rasionalitas dari pikiran. ${ }^{68}$

Whitehead mengatakan bahwa sains bukanlah satu-satunya ilmu pengetahuan yang memiliki kebenaran mutlak atau benar secara objektif untuk memahami fakta-fakta tentang alam semesta. Pada dasarnya, sains mengawali pengamatannya dari abstraksi pikiran menuju fakta sehingga akhirnya menembus setiap peluang fakta. ${ }^{69}$ Oleh sebab itu, sering muncul kekeliruan, sebab fakta direduksi dan disesuaikan dengan bentuk abstraksi dari pikiran itu sendiri. Kebenaran matematika sebagai simbol pemikiran abstrak manusia dikorelasikan atau dipraktikkan pada benda-benda, padahal tidak semua bisa cocok. Pada hakikatnya, matematika merupakan ilmu pengetahuan yang memandang eksistensi realitas yang bersifat benda mati, sepotong-sepotong, dan mengunakan metode deduksi atau induksi. ${ }^{70}$ Di sinilah juga letak penyebab matematikawan tidak dapat mencapai titik tertentu pengalaman dan kenikmatan estetis alam semesta. ${ }^{71}$ Selain itu, matematika dengan diam-diam selalu memunculkan beberapa syarat atau membuat pengandaian tertentu, yang sebenarnya tidak dapat dipegang atau bisa membingungkan asal tolok ukur kebenaran pengandaian tersebut. ${ }^{72}$ Artinya, kepastian matematika sangat bergantung pada generalisasi abstraksi yang sempurna. ${ }^{73}$

Dalam hal itu, matematikawan mencari apa yang paling sempurna, sebagaimana juga agama monoteis dan agama-agama Timur, yang juga mencari hal-hal paling sempurna dalam kehidupan. Namun, ada perbedaan, yakni bahwa yang terakhir ini tidak hanya mencari dan menemukan kesempurnaan sebagai pengetahuan, tetapi juga menghidupi prinsip utama itu dalam kehidupan sehari-hari. ${ }^{74}$ Artinya, ada unsur spiritual di dalam pencariannya, yang memungkinkan para pencarinya semakin kaya akan makna ilmu pengetahuan, meskipun tanpa menggunakan metode deduksi atau induksi. Pada tataran ini, para mistikus pun dapat terlibat untuk berpikir secara intuitif, imajinatif, integral, dan holistik kendati tidak terikat dengan metode tertentu, namun dengan menggunakan metode 'spiritual' (menurut Capra, kosmik), sebagai metode epistemologis dalam membangun dasar-dasar ilmu pengetahuan. 


\section{Fritjof Capra}

Pandangan F. Capra (lahir 1939) tentang kelemahan dan konsekuensi modernitas dapat dijelaskan lebih lanjut, khususnya terkait sains dan dunia ilmiah. Ada dua hal penting pemikiran Capra yang menyoroti kekeliruan sains dalam mempersepsi realitas. Pertama, kegagalan para ilmuwan dalam menafsirkan agama dan tradisi terkait relasinya dengan alam. Kedua, ketidakmampuan para fisikawan modern untuk memahami bentuk paradoks atau misteri alam semesta telah menjadi pembenaran keterbatasan atau kelemahan ilmiah untuk mencari kebenaran.

(a) Kekeliruan menafsirkan kebijaksanaan agama-agama dan tradisitradisi. Pemikiran Descartes dan Newton telah merambah ke seluruh ilmu pengetahuan hingga sekarang. Inti pemikiran Descartes dan Newton, yakni pada pencarian prinsip fundamental kehidupan di alam semesta ini. Menurut Capra, perubahan persepsi terhadap alam dimulai pada abad ke-17 dan telah membawa implikasi atau konsekuensi besar, misalnya, perubahan wajah agama, pandangan tentang alam semesta, kultur, dan pemahaman manusia tentang dirinya dalam relasinya dengan alam. Peradaban modern atau keberhasilan dunia ilmiah ternyata tidak serta merta membawa perubahan positif dalam kehidupan manusia, melainkan sesuatu yang menakutkan terhadap keutuhan eksistensi manusia dan juga totalitas kosmos, atau yang disebut Capra sebagai sisi gelap pertumbuhan. ${ }^{75}$ Kelemahan modernitas ialah tidak mampu melihat sisi negatif sebagai konsekuensi kesalahannya ketika mendekonstruksi alam dan agama. Rujukan contoh, misalnya, ialah masa sebelum atau antara tahun 15001700, ketika pandangan manusia (termasuk agama) terhadap alam bersifat hidup, dan bahwa alam bernilai pada dirinya sendiri. Pada masa itu, manusia hidup dalam komunitas kecil dengan relasi yang erat, termasuk juga dengan alam. Mereka menjalani kehidupan di alam ini dengan pengertian hubungan yang organik dan prinsip bahwa kebutuhan masyarakat umum lebih utama daripada kepentingan pribadi. ${ }^{76}$

Karakter ilmu pengetahuan di Abad Pertengahan lebih didasarkan pada penalaran dan keimanan, yang bertujuan untuk memahami makna dan signifikasi segala sesuatu, namun bukan untuk tujuan peramalan dan pengendalian. ${ }^{77}$ Artinya, penghayatan terhadap alam, tradisi, dan agama pada waktu itu memberikan kesuburan pada dimensi spiritual manusia, yaitu kemampuan berpikir bolistik dan integral daripada yang bersifat 
fragmentaris. Referensi Capra kepada Ronald D. Laing menemukan bahwa tidak ada kekuatan atau obsesi lebih besar yang sebanding dengan semangat para ilmuwan untuk mengukur (kuantifikasi) alam di sepanjang sejarah. Akan tetapi, para ilmuwan tidak menyadari bahwa mereka telah mengesampingkan dan membunuh rasa pemandangan, suara, rasa bau, dan sentuhan, sehingga mereka mengalami krisis di dimensi estetika, etika, kualitas, bentuk, atau semua bentuk dari perasaan, motif, kehendak, kesadaran integral, jiwa, dan roh. $^{78}$

Para filsuf dan teolog di Abad Pertengahan, termasuk juga para filsuf helenis jauh sebelumnya, berikhtiar mencari tujuan utama berbagai fenomena atau prinsip causa prima dari seluruh kosmos, yakni sosok yang sering disebut sebagai Tuhan, Roh, kebenaran tertinggi moral, atau signifikasi tertinggi yang tidak ternamai atau diketahui oleh indra, tetapi yang sungguh-sungguh nyata dan hadir dalam kehidupan dan realitas. Pemikiran Abad Pertengahan dan zaman helenis seperti ini masih dipertahankan oleh Filsafat Timur, termasuk juga Taoisme, sampai sekarang.

(b) Ketidakmampuan fisikawan modern memahami paradoks atau misteri semesta sebagai pembenaran keterbatasan ilmiah untuk mencari kebenaran. Menurut Capra, di abad ke-20 ini, fisikawan seperti Max Planck, Albert Einstein, Niels Bohr, Louis De Broglie, Erwin Schrodinger, Wolfgang Pauli, Werner Heisenberg, dan Paul Dirac, menghadapi tantangan serius soal kemampuan mempersepsi realitas dan alam semesta. ${ }^{79}$ Setiap kali mereka bertanya kepada alam dan melakukan eksperimen dengan menggunakan teori atom, alam selalu menjawab dengan hasil yang sangat paradoksal dan absurd. Ketika semakin berambisi atau semakin kuat ingin memperjelas situasi alam, mereka pun semakin tajam berhadapan dengan paradoks dari alam itu sendiri. ${ }^{80}$ Kalau demikian, metode Descartes, Hobbes, Bacon, dan Newton tidak bisa dipakai sebagai satu-satunya jalan untuk mencapai kebenaran tentang realitas dan alam semesta. Capra sadar bahwa dunia ilmiah harus terbuka terhadap berbagai misteri alam, sebab alam sesungguhnya bukanlah benda mati, tetapi realitas yang bersifat organis.

Para fisikawan modern perlu menyadari bahwa mereka memiliki keterbatasan dalam memahami paradoks alam. Mereka menyadari bahwa perlu menyerahkan keterbatasan tersebut kepada filsuf, atau situasi yang sering disebut sebagai "implikasi filosofis" sains modern. ${ }^{81}$ Para fisikawan 
modern tidak bisa memandang dunia sebagai sebuah mesin yang terdiri atas kumpulan objek, melainkan menggambarkannya sebagai sebuah keseluruhan dinamis yang tidak dapat dipecah-pecah, sebab seluruhnya saling berkaitan dalam satu kesatuan proses kosmik. ${ }^{82}$ Pada waktu fisikawan menembus ke dalam materi, ia akan berhadapan dengan kenyataan bahwa alam tidak menunjukkan adanya balok-balok bangunan dasar yang terpisah-pisah, melainkan tampak sebagai jaring-jaring keterkaitan yang rumit berbagai bagian, dari suatu keseluruhan yang utuh. ${ }^{83}$

Menurut Capra, di sinilah kehadiran mistikus menawarkan jalan keluar bagi pembebasan manusia modern di tengah kebingungan ilmiah yang hanya mengandalkan rasionalitas dan eksperimen. Ia juga melihat bahwa zaman sekarang adalah era kejayaan dan kebangkitan mistis, yang selama ini cenderung dicurigai, tidak diperhitungkan, dianggap tidak ilmiah atau irasional di tengah-tengah legitimasi ilmiah. ${ }^{84}$ Kekuatan intuisi dan imajinasi para mistikus merupakan salah satu jalan keluar untuk memahami paradoks alam. Menurut Capra, untuk memahami karakter paradoksal alam, diperlukan kemampuan dan paradigma holistik, organik, dan ekologis. Hal ini selaras dengan pemikiran Niels Bohr yang pernah memperkenalkan teori komplementaritas. Menurut Bohr, teori komplementaritas merupakan alternatif yang mensintesiskan berbagai teori yang memiliki kredibilitas untuk memahami misteri alam, misalnya, dengan menggabungkan deskripsi tentang alam sebagai gambaran partikel dan gambaran alam sebagai gelombang. ${ }^{85}$ Walaupun kedua teori ini masih memiliki keterbatasan, keduanya saling membantu bila disintesiskan ke dalam suatu teori yang baru. Menurut Capra, teori komplementaritas ini tecermin juga dalam Taoisme.

Pada saat mempersepsi realitas, manusia tidak langsung memberikan reaksi terhadap alam, melainkan mengolahnya lewat refleksi. ${ }^{86}$ Dengan demikian, refleksi manusia ini berpotensi menjadi pokok kesalahan di dalam dunia ilmiah. Kesalahan metodologis yang digunakan untuk membebaskan diri dari belenggu alam dan kultur-sosial telah menyebabkan krisis-krisis besar yang hampir tidak bisa dibendung lagi, kecuali dengan mengubah kesadaran manusia itu sendiri. 


\section{Simpulan}

Manusia pernah mencoba menjawab berbagai persoalan dalam kehidupannya secara mitologis, tetapi manusia adalah makhluk rasional yang haus akan pengetahuan dan memiliki ketidakpuasan, keraguan, dan hasrat selalu bertanya. Maka dari itu, manusia hidup dalam pencarian, dan berusaha membebaskan diri dari kemelut di sekitar jawaban dari mitos dan agama. Mitos menjadi tahap awal perkembangan filsafat, agamaagama monoteis, dan juga dunia ilmiah modern. Seiring perkembangan zaman, keberhasilan ilmu dan sains telah dirasakan dalam membongkar berbagai mitos dan klaim kebenaran agama. Perubahan paradigma manusia tentang alam semesta adalah konsekuensi pencarian manusia akan prinsip fundamental realitas. Dengan demikian, tumbangnya mitologi di tengah legitimasi sains menjadi simbol lahirnya manusia yang rasional. Agama pernah terseret ke dalam keraguan-keraguan rasional yang dimunculkan sains.

Kritik terhadap pendekatan sains pada realitas dan kebenaran, terutama yang diinspirasi oleh Whitehead dan Capra, memunculkan kebangkitan kembali "yang spiritual" sebagai pendekatan yang lebih menyeluruh (holistik) dan lebih terbuka pada berbagai paradoks realitas. Mistisisme tidak perlu diadili sebagai irasional dan antisains, sebab pada dasarnya ilmu dan sains berpijak pada keinginan untuk mengetahui yang mengungkapkan rasa hormat pada yang ultim di dalam realitas. Kalau ditemukan adanya krisis spiritual di zaman kini, tampaknya manusia perlu berdistansi dan memandang kembali hasil-hasil sains dan ilmu pengetahuan yang dicapainya secara menyeluruh. Spiritualitas adalah soal kemampuan memandang keberadaan suatu jaringan keterkaitan yang membentuk serta menjaga keseimbangan alam semesta dan realitas kosmik. Di dalamnya manusia menemukan autentisitas dirinya sebagai manusia.

\section{Bibliografi:}

Bertens, Kees. Sejarah Filsafat Yunani: dari Thales ke Aristoteles. Yogyakarta: Kanisius, 1999.

Capra, Fritjof. Titik Balik Peradaban: Sains, Masyarakat, dan Kebangkitan Kebudayaan. Judul asli: The Turning Point: Science, Society and The Rising Culture [New York: Bantam Books, 1982]. Terj. M. Thoyibi. Yogyakarta: Yayasan Bentang Budaya, 2000. 
Hadiwijono, Harun. Seri Sejarah Filsafat Barat. Yogyakarta: Kanisius, 1980. Hamersma, Harry. Tokoh-Tokoh Filsafat Modern. Jakarta: Gramedia, 1983.

Leahy, Louis. Esai Filsafat untuk Masa Kini: Telaah Masalah Roh-Materi Berdasarkan Data Empiris Baru. Jakarta: Pustaka Utama Grafiti, 1991. Mangunwijaya, Yusuf B. Pasca-Indonesia: Pasca-Einstein. Yogyakarta: Kanisius, 1999.

Piliang, Yasraf Amir. Sebuah Dunia yang Menakutkan: Mesin-Mesin Kekerasan dalam Jagat Raya Chaos. Bandung: Mizan, 2001.

Rapar, Jan Hendrik. Pengantar Filsafat. Yogyakarta: Kanisius, 1996.

Smith, Huston. Kebenaran yang Terlupakan: Kritik atas Sains dan Modernitas.

Judul asli: Forgotten Truth: The Common Vision of World's Religious [New York: Oxford University Press, 1990]. Terj. Inyiak Ridwan Muzir. Yogyakarta: IRCiSoD, 2001.

Sugiharto, I. Bambang. Postmodernisme: Tantangan bagi Filsafat. Yogyakarta: Kanisius, 1996.

Whitehead, Alfred North. Sains dan Dunia Modern. Judul asli: Science and the Modern World [New York: A Mentor Book, 1960]. Terj. O. Komarudin. Bandung: Nuansa, 2005.

\section{Endnotes:}

1 Mariasusai Dhavamony, Fenomenologi Agama, judul asli: Phenomenology of Religion [Rome: Gregorian University Press, 1973] terj. A. Sudiarja (Yogyakarta; Kanisius.1995) 221236.

2 Jan Hendrik Rapar, Pengantar Filsafat, (Yogyakarta: Kanisius, 1996) 16-20.

3 Louis Leahy, Esai Filsafat untuk. Masa Kini: Telaah Masalab Roh-Materi Berdasarkan Data Empiris Baru (Jakarta: Pustaka Utama Grafiti, 1991) 81-86.

4 Anthony Giddens, Tumbal Modernitas: Ambruknya Pilar-Pilar Keimanan, judul asli: The Consequences of Modernity [California: Stanford University Press, 1990], terj. Mohammad Yamin (Yogyakarta: IRCiSod, 2001) 53-63.

5 John Powel, Beriman untuk. Hidup, Beriman untuk. Mati, judul asli: A Reason to Live! A Reason to Die! A New Look at Faith in God [1975] terj. A. Widyamartaya (Yogyakarta: Kanisius, 1991) 15-33.

6 Kata pengantar dari Armahedi Mazhar pada Fritjof Capra, The Tao of Physics: Menyingkeapi Kesejajaran Fisika Modern dan Mistisisme Timur (Yogyakarta: Jalasutra, 2000) ix; judul asli: The Tao Physics: An Exploration of the Parallels between Modern Physics and Easter Mysticism [Boston: Shambhala Publications, 2000) terj. Aufiya Ilhamal hafizh.

7 Fritjof Capra lahir pada 1 Februari 1939 di Wina, Austria. Ia memperoleh gelar Ph. D dalam bidang fisika teoretis di Universitas Vienna, Amerika, pada 1966. Ia aktif melakukan sejumlah riset dalam bidang fisika energi tinggi atau partikel dan sistem di beberapa universitas di Eropa dan Amerika, antara lain di Universitas Paris 
(1966-1968), di Universitas Santa Cruz - California (1968-1970), Stanford Linear Accelerator Center University (1970), di Universitas Imperial College - London (1971-1974), dan di Universitas Lawrence Berkeley Labolatory - California (19751988). Selain itu, ia mengajar di Universitas Santa Cruz dan Berkeley - California, dan di Universitas San Francisco. Capra merupakan anggota Fundamental Physics Group di Berkeley, yakni sebuah komunitas yang didirikan oleh Elizabeth Rauscher dan Georger Weissmann, yang melakukan pertemuan setiap minggu untuk membahas fisika kuantum dan filsafat, khususnya berbagai implikasi filosofis dari sains modern. Selain itu, Capra merupakan direktur Pusat Ekoliterasi (Center for Ecoliteracy) yang membahas masalah ekologi dan sistem berpikir baru terhadap pendidikan dasar dan menengah di Berkeley, California.

8 I. Bambang Sugiharto, Postmodernisme: Tantangan bagi Filsafat (Yogyakarta: Kanisius, 1996) 24.

$9 \quad$ Ibid., 63.

10 Dalam tulisan ini, pemahaman saya tentang yang spiritual pertama-tama bukan perkara suci-profan, baik-jahat, berdosa-tidak berdosa, rendah hati-tinggi hati, atau egoistis-altruistis, melainkan "yang spiritual" merupakan paradigma berpikir atau suatu prespektif seseorang tentang segala sesuatu secara holistik dan integral.

11 Rapar, Pengantar Filsafat, op. cit., 16-17.

12 Ilmu biologi (anatomi, biofisika, genetika, ekologi, fisiologi, taksonomi, virulogi, zoology), ilmu fisika (fisika material, optik, mekanika kuantum, theormodinamika, astronomi, fisika nuklir, kinetika, dinamika), ilmu kimia (kimia analitik, elektrokimia, kimia organik dan anorganik, kimia polimer, theormokimia), ilmu bumi (ilmu lingkungan, geodesi, geologi, hidrologi, meteorologi, paleontologi, oceanografi), ilmu sosial (sejarah, antropologi, teologi, hukum, ekonomi, bisnis) dan lain-lain, dipengaruhi pengalaman takjub, sehingga manusia termotivasi untuk melakukan penelitian.

13 Frans Dähler dan Julius Chandra, Asal dan Tujuan Manusia (Yogyakarta: Kanisius, 1976) 56-57.

14 Fritjof Capra, Titik Balik Peradaban: Sains, Masyarakat dan Kebangkitan Kebudayaan, judul asli: The Turning Point; Science, Society and The Rising Culture (New York: Bantam Book. 1982), terj. M. Thoyibi (Yogyakarta; Yayasan Bentang Budaya, 2000) 35.

15 Ibid., 11.

16 Yasraf Amir Piliang, Sebuab Dunia yang Menakutkan: Mesin-Mesin Kekerasan dalam Jagat Raya Chaos (Bandung: Mizan, 2001) 21-25.

17 Kees Bertens, Sejarah Filsafat Yunani (Yogyakarta: Kanisius, 1975) 14-18.

18 Ibid., 15.

19 Ibid., 18-19.

20 Lih. Erich Fromm, Manusia menjadi Tuban: Pergumulan antara Tuban Sejarab dan Tuban Alam, judul asli: You Shall Be As God (London: Flamingo, 1978), terj. Evan Wisastra, dkk. (Yogyakarta: Jalasutra, 2003) 10-15.

21 Drs. H. Muzairi, M.A, Eksistensialisme Jean-Paul Sartre: Sumur Tanpa Dasar Kebebasan Manusia (Yogyakarta: Pustaka Pelajar, 2002) 131-151.

22 Permasalahan letak geografis menentukan kultur, mentalitas, termasuk gaya hidup, cara berpikir, cara bertindak, dan bahkan cara seseorang menghayati hidup, misalnya, cara hidup orang Indonesia yang tinggal di daerah tropis yang penuh dengan tumbuh-tumbuhan, berbeda dari cara hidup orang Arab atau Irak yang tinggal di padang gurun yang gersang. 
23 Franz-Magnis Suseno, Manusia dalam Pijar-Pijar Kekayaan Dimensinya, ed. FX. Mudji Sustrisno (Yogyakarta: Kanisius, 1993) 25-30.

24 Kata pengantar dari Alex Lanur dalam buku terjemahan John Stuart Mill, On Liberty: Perihal Kebebasan (Jakarta: Yayasan Obor, 2005) x-xvi.

25 Capra, Titik Balik Peradaban, op. cit., 51-83.

26 Bryan Magee, The Story of Phylosophy: Kisah tentang Filsafat, judul asli: The Story of Phylosopply

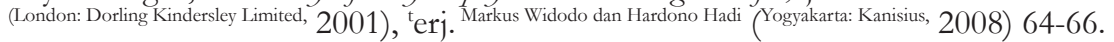

27 Ibid., 66.

28 Ibid.

29 Ibid.

30 Ibid., 67.

31 Ibid.

32 Galilei merupakan orang yang pertama kali membuat dan menggunakan teleskop yang dipakai untuk mengamati jagat raya, dan ia berhasil mengamati bentuk Venus dan menemukan beberapa satelit Yupiter. Ia juga menemukan termometer dan mesin pendulum yang membuat teknik pembuatan jam menjadi lebih akurat.

33 Ada polemik baru, yang menurut Capra justru modernitas merupakan sejarah pusat kesombongan dan kepercayaan diri manusia yang paling mengerikan dan berbahaya.

34 Latar belakang pendidikan Bacon ialah politik, hukum, sastra, filsafat, dan sains. Ia menempuh pendidikan di Cambridge. Selain itu, hampir seluruh hidupnya dijalani di lingkungan pengadilan mulai usia 23 tahun, sebagai anggota parlemen jaksa agung muda, jaksa agung, pejabat pemegang stempel agung, dan pejabat tertinggi dalam pengadilan.

35 Capra, Titik Balik Peradaban, op. cit., 55.

36 Ibid., 56.

37 Harun Hadiwijono, Seri Sejarah Filsafat Barat (Yogyakarta: Kanisius, 1980) 15.

38 Ibid.

39 Magee, Kisah tentang Filsafat, op. cit., 78.

40 Milton D. Hunnex, Peta Filsafat: Pendekatan Kronologis dan Tematis, judul asli: Chronological and Thematic Charts of Philosophies and Philosophers (Michigan: Academic Books, 1986), terj. Zubair (Jakarta: Teraju, 2004) 108-109.

41 Magee, op. cit., 79.

42 Harry Hamersma, Tokoh-Tokoh Filsafat Modern (Jakarta: Gramedia, 1983) 6.

43 Capra, Titik Balik Peradaban, op. cit., 57.

44 Ibid.

45 Ibid., 56.

46 Hamersma, op. cit., 8.

47 Capra, op. cit., 58.

48 Ibid.

49 Hal ini kontradiktif dengan pemikiran Capra dan mistisisme Timur yang melihat bahwa alam semesta sebagai makro memiliki tujuan dan dimensi spiritual, sebagaimana tubuh manusia yang bersifat mikro.

50 Capra, op. cit., 62.

51 Ibid., 59. 
52 Inspirasi ini diperoleh dari buku Capra, The Hidden Connection, yakni seluruh alam semesta dan bahkan manusia berada dalam dimensi 'kapitalisme', yakni digerakkan tujuan karena ada makna. Dalam pemikiran Capra, kata 'makna' merupakan bagian dari triloginya yang keempat.

53 Capra, Titik Balik Peradaban, op. cit., 65.

54 Ibid., 66.

55 Ada cerita bahwa Newton memperoleh inspirasi tentang hukum gravitasi saat melihat sebuah apel jatuh dari pohonnya. Melalui pengalaman tersebut, ia menyadari bahwa buah apel tersebut ditarik ke arah bumi oleh kekuatan yang sama, seperti planetplanet tertarik ke arah matahari. Newton menyajikan teorinya tentang dunia beserta hukum gravitasinya secara rinci di bukunya yang berjudul Mathematical Principles of Natural Philosophy atau sering disingkat Principia.

56 Capra, Titik Balik Peradaban, op. cit., 70.

57 Ibid.

58 Huston Smith, Kebenaran yang Terlupakan: Kritik atas Sains dan Modernitas, judul asli: Forgotten Truth: The Common Vision of the World's Religions (New York: Oxford University Press, 1990), terj. Inyiak Ridwan Muzir (Yoyakarta: IRCiSoD, 2001) 147.

59 Capra, op. cit., 72.

60 Bertens, Sejarah Filsafat Yunani, op. cit., 35-37.

61 Capra, op. cit., 153-252.

62 Y. B. Mangunwijaya, Pasca-Indonesia: Pasca-Einstein (Yogyakarta: Kanisius, 1999) 209223.

63 Ibid., 217.

64 Pius Pandor, CP., Ex Latina: Dari Bahasa Latin Muncul Kejernihan Jakarta: Obor, 2010) 25-27.

65 Francis Lim, Filsafat Teknologi: Don Ihde tentang Dunia, Manusia, dan Alat (Yogyakarta: Kanisius, 2008) 29-32.

66 Antonius Subianto Bunyamin, Teknologi Madya Schumacher; Gagasan Teknologi Manusiawi (Bandung: Skripsi di Fakultas Filsafat, Universitas Katolik Parahyangan, 1994) 45-54.

67 Whitehead lahir pada 15 Februari 1861 di Ramstage, Inggris. Whitehead adalah seorang matematikawan, kritikus ilmu pengetahuan, dan dosen di beberapa universitas terkenal, seperti Trinity College di Cambridge dan Harvard di Boston. Selain itu, ia juga adalah seorang filsuf metafisika atau sering dikenal sebagai filsuf perintis Filsafat Proses.

68 Alfred North Whitehead, Sains dan Dunia Modern, judul asli: Science and the Modern World (New York: Mentor Book, 1960), terj. O. Komarudin (Bandung: Nuansa, 2005) 39.

69 Ibid.

70 Ibid., 40.

71 Ibid., 35.

72 Ibid.

73 Ibid., 34.

74 Ibid., 46.

75 Capra menguraikan sisi gelap pertumbuhan modernitas dengan sangat mendetil dalam bukunya, Titik Balik Peradaban, op. cit. 
Melintas Vol. 34, No. 2, 2018

76 Ibid., 51.

77 Ibid., 52.

78 Ibid., 54.

79 Ibid., 87.

80 Ibid., 86.

81 Ibid., 88.

82 Ibid.

83 Ibid., 91.

84 Ibid., 89.

85 Ibid., 91.

86 C. A. Van Peursen, Orientasi di Alam Filsafat (Jakarta: Gramedia, 1983) 207. 